\title{
PENGARUH BENTUK TES FORMATIF ASSOSIASI PILIHAN GANDA DENGAN REWARD DAN PUNISHMENT SCORE PADA PEMBELAJARAN MATEMATIKA SISWA SMA
}

\author{
Oleh: \\ 1) Slamet, ${ }^{2)}$ Samsul Maarif \\ ${ }^{1,2}$ Pendidikan Matematika FKIP UHAMKA \\ 2 sams_andromeda@yahoo.com
}

\begin{abstract}
ABSTRAK
Penelitian ini mengkaji dan menemukan bentuk tes formatif yang efektif yaitu dengan penggunaan bentuk tes formatif assosiasi pilahan ganda dengan reaward dan punishment score pada pembelajaran matematika siswa SMA. Adapun objek penelitian yang akan dilakukan pada penelitian ini adalah SMA Provinsi DKI Jakarta. Sampel yang diambil adalah SMA N 16 Jakarta Barat dan SMA N 46 Jakarta Timur. Tes formatif adalah tes yang diberikan secara periodik dalam proses pembelajaran yang bertujuan untuk memantau perkembangan siswa. Selain itu, sebagai bentuk evaluasi pembelajaran tes formatif diberikan untuk mengetahui bagaimana umpan balik siswa dalam proses pembelajaran untuk perbaikan konteks pembelajaran di dalam kelas. Dari hasiil pengujian diperoleh p-value (Asymp Sig) kelas eksperimen adalah 0,355 $>0,05=\alpha$, dan $p$-value (Asymp Sig) kelas kontrol adalah $0,031<0,05=\alpha$, maka hipotesis $\mathrm{H}_{0}$ ditolak. Hal ini menunjukkan adanya pengaruh pemberian tes formatif bentuk asosiasi pilihan ganda dengan reward score terhadap hasil belajar matematika siswa pada pokok bahasan turunan fungsi. Dengan demikian, tes formatif assosiasi pilihan ganda dengan reward dan punishment score yang cocok dengan pembelajaran matematika SMA efektif diterapkan dalam proses pembelajaran terutama dalam evaluasi pembelajaran.
\end{abstract}

Kata Kunci : Tes Formatif assosiasi pilahan ganda, reaward dan punishment score, Hasil Belajar

\begin{abstract}
This study reviews and find effective forms of formative tests is to use a test double increments formative associations with reaward and punishment scores of high school students in learning mathematics. The object of the research to be conducted in this study were high school DKI Jakarta. Samples taken are SMAN 16 Jakarta, West Jakarta and East High School N 46. Formative test is a test that is administered periodically in the learning process that aims to monitor student progress. In addition, as a form of formative evaluation of learning tests are given to determine how the student feedback for improvement in the learning process in the classroom learning context. Hasiil obtained from testing the p-value (Asymp Sig) is an experimental class $0.355>0.05=\alpha$, and the p-value (Sig Asymp) control class is $0.031<0.05=\alpha$, then $\mathrm{H} 0$ is rejected. This shows the effect of giving formative test multiple choice form of association with reward math scores on learning outcomes of
\end{abstract}


students on the subject of the derivative function. Thus, multiple-choice tests formative associations with reward and punishment score that matches the effective teaching high school mathematics implemented in the learning process, especially in the evaluation of learning.

Keywords : association Formative Test double increments, reaward and punishment scores, Learning Outcomes

\section{PENDAHULUAN}

Pendidikan merupakan suatu proses yang dinamis dan senantiasa dituntut untuk selalu menyesuaikan diri dengan kebutuhan masyarakat dan perkembangan teknologi. Pendidikan juga memiliki kontribusi besar dalam mempersiapkan manusia yang berkualitas dan mengarahkan siswa untuk memahami perannya sebagai manusia yang bertanggung jawab untuk melanjutkan dan meningkatkan pembangunan. Untuk meningkatkan pembangunan diperlukan sistem pendidikan yang dapat mempengaruhi sistem belajar mengajar diantaranya kurikulum, buku, sarana belajar, guru dan siswa, serta evaluasi hasil belajar. Oleh karena itu, dituntut penyesuaian dalam segala faktor yang mempengaruhi pelaksanaan agar sistem pendidikan dapat tercapai dengan optimal.

Faktor yang sangat penting dalam pelaksanaan sistem pendidikan adalah evaluasi belajar atau pencapaian hasil belajar siswa. Keberadaan evaluasi belajar sangat diperlukan dalam kegiatan belajar mengajar berlangsung karena terdapat proses pembelajaran, penilaian, dan evaluasi. Evaluasi diperlukan untuk mengetahui sejauh mana keberhasilan guru dalam memberikan materi serta sejauh mana siswa menyerap materi yang disajikan. Oleh karena itu, perlu diciptakan alat untuk mendiagnosis atau mengukur keadaan individu tesebut, alat pengukur itulah yang sering disebut dengan tes.

Tes berfungsi untuk mengetahui adanya perbedaan antar individu, tes juga dapat memberikan dorongan atau motivasi kepada mereka untuk dapat memperbaiki, meningkatkan, dan mempertahankan prestasi dalam kegiatan belajar mengajar.

Guru seharusnya memberikan sebuah tes pada setiap akhir pembelajaran atau tes formatif untuk mengetahui sejauh mana siswa mengerti dan memahami materi yang telah diajarkan. Kenyataannya, guru masih jarang memberikan tes formatif di setiap akhir pembelajaran.

Bentuk pemberian tes formatif yang selama ini digunakan cenderung berupa uraian saja atau pilihan ganda saja. Walaupun, di dalam buku evaluasi pendidikan terdapat banyak sekali macam-macam bentuk tes yang dapat diberikan guru kepada siswa, akan tetapi faktor-faktor yang tidak mendukung seperti kurangnya kesiapan guru dalam kegiatan belajar mengajar tiap harinya, waktu yang sangat singkat dalam 
kegiatan belajar mengajar dan kesibukan guru itu sendiri sehingga sudah tidak terpikirkan lagi untuk membuat soal tes dalam bentuk yang bervariasi.

Variasi bentuk tes diperlukan karena semakin canggih dan berkembangnya zaman sehingga pemerintah ikut menetapkan standar kelulusan Sekolah Menengah Atas (SMA) untuk menuju universitas yang berkualitas dengan cara menggunakan sebuah tes. Tes yang dilakukan tersebut bukan hanya pilihan ganda atau uraian biasa, melainkan menggunakan tipe tes berupa soal asosiasi pilihan ganda dan juga uraian terstruktur. Oleh karena itu, guru dituntut untuk lebih kreatif agar siswa terbiasa dalam menghadapi permasalahan pada saat mengerjakan jenis tes formatif tersebut.

Tes formatif bentuk asosiasi pilihan ganda sebenarnya bisa menjadi pilihan oleh guru sebagai salah satu tes formatif, karena bentuk soal yang mulai variatif dengan menggunakan sistem asosiasi yakni penyebaran jawaban dan membutuhkan pengetahuan siswa yang lebih. Namun, guru masih kesulitan untuk menyusun tes formatif bentuk asosiasi pilihan ganda dikarenakan kurangnya pengetahuan tentang evaluasi pendidikan itu sendiri atau bisa juga dikarenakan kurangnya kesabaran untuk menyusun tes asosiasi pilihan ganda ini yang sudah lebih rumit dibandingkan soal pilihan ganda biasa. Meskipun sudah dimodifikasi menjadi asosiasi pilihan ganda, kemungkinan bagi siswa untuk bermain spekulasi dan tebak terka dalam memberikan jawaban soal ini masih sangat terbuka. Oleh karena itu, tes hasil belajar asosiasi pilihan ganda dianggap masih kurang efektif.

Adapun tes uraian adalah bentuk tes yang terdiri dari suatu pertanyaan atau perintah yang memerlukan jawaban bersifat pembahasan atau uraian kata-kata yang relatif panjang. Bentuk tes uraian ini juga dapat digolongkan menjadi tes uraian bentuk bebas atau terbuka dan tes uraian bentuk terbatas atau terstruktur. Adapun tes uraian terstruktur yang dikehendaki muncul dari siswa adalah jawaban yang sifatnya sudah lebih terarah atau dibatasi atau terstruktur. Tes hasil belajar uraian terstruktur ini dijadikan sebagai salah satu alat pengukur hasil belajar yang tepat digunakan apabila pembuat soal disamping ingin mengungkap daya ingat dan pemahaman siswa terhadap materi pelajaran yang ditanyakan dalam tes, juga ingin mengungkap kemampuan siswa dalam memahami berbagai macam konsep.

Kebiasaan buruk siswa menebak, mencontek, dan kerjasaama menjawab soal perlu diatasi. Salah satu cara mengatasi hal ini adalah dengan memberikan hukuman (punishment) pada siswa yang melakukan kebiasaan buruk tersebut dan memberikan hadiah (reward) pada siswa yang tidak melakukan hal tersebut atau melakukan hal benar. Namun pemeberian reward dan punishment pada siswa tidak boleh sembarangan, untuk itu sebaiknya reward dan punishment diberikan dalam bentuk skor pada penskoran butir-butir soal tes yang diberikan, salah satunya tes formatif.

Selain untuk mengurangi kebiasaan buruk siswa, pemberian reward score (penambahan skor) dan punishment score (pengurangan skor) juga bisa 
meningkatkan motivasi belajar dan kepercayaan diri siswa dalam pembelajaran matematika. Banyak dampak positif dalam pembelajaran dengan diberikannya reward yaitu hubungan guru dan siswa menjadi lebih erat, perhatian siswa pada matematika lebih meningkat, merangsang dan meningkatkan motivasi belajar matematika, meningkatkan kegiatan belajar matematika, dan membina tingkah laku siswa yang produktif. Sementara dampak pemberian punishment adalah menyadarkan siswa akan kesalahannya sehingga mereka akan termotivasi untuk menjadi lebih baik.

\section{Kajian Pustaka}

\section{Matematika}

Riedesel, Schwartz, dan Clements (1996) menulis beberapa alasan kenapa matematika perlu diajarkan, di antaranya yang bersesuaian dengan penelitian ini, bahwa matematika adalah pemecahan masalah, suatu aktivitas untuk menemukan dan mempelajari pola maupun hubungan, cara berpikir dan alat untuk berpikir, berguna untuk semua, dan kemampuan matematik.

Secara etimologis, matematika berarti ilmu pengetahuan yang diperoleh dengan bernalar, ia lebih menekankan aktivitas dalam dunia rasio (penalaran). Kemampuan bernalar ini dapat dilihat dari cara memecahkan persoalan-persoalan matematika maupun persoalan-persoalan kehidupan (Suherman, dkk., 2003). Matematika tidak hanya membantu siswa sebagai alat penunjang dalam mempelajari ilmu lain, melainkan juga dalam rangka pembentukan sikap dan kepribadian agar dapat berpikir logis, rasional, dan sistematis.

Matematika bersifat aksiomatik karena ia berangkat dari prinsip-prinsip umum yang diterima tanpa bukti, ia lahir dari unsur pangkal yang menjadi pijakan bagi definisi konsep dalam matematika. Dalam pengembangannya matematika membahas tentang konsep-konsep secara tersendiri maupun hubungan yang ada diantara konsep tersebut yang akan melahirkan konsep baru. Karena matematika dipenuhi oleh konsep-konsep, juga konsep yang ada (baru) dibentuk oleh beberapa konsep sebelumnya yang memiliki keterkaitan, sehingga matematika dikatakan sebagai ilmu yang menjaga hierakis dan sistematika. Mempelajari matematika berarti berhadapan dengan cukup banyak kesepakatan yang harus dipenuhi dan diikuti, jika tidak maka akan meruntuhkan bangunan matematika sebagai sebuah sistem yang utuh.

Karena matematika penuh dengan konsep yang abstrak, maka penanaman konsep tidak cukup hanya melalaui hafalan dan ingatan tetapi harus dimengerti dan dipahami melalui suatu proses berpikir dan beraktivitas secara nyata. Kemampuan mengkonkritkan konsep matematika akan dapat membantu proses penguasaan materi pelajaran matematika, ini dapat dilakukan dengan bantuan tes assosiasi pilihan ganda ke arah pembelajaran visualisasi dan kinestetik. Tahap berikutnya 
dalam belajar matematika adalah menuntut kemampuan mengabstraksi, menganalisis secara deduktif dan induktif semua bangunan atau sistem maupun hubungan yang ada di dalamnya. Karena itu pelajaran matematika pada setiap jenjang pendidikan memiliki keterkaitan satu dengan lainnya, untuk menguasai suatu sistem maka harus didahului dengan penguasaan terhadap sistem yang lain. Oleh karena itu penanaman konsep keliru pada sistem yang menjadi prasyarat akan mengakibatkan kekeliruan pula pada semua sistem yang berhubungan dengan sistem tersebut.

Dari semua cabang matematika, yang menjadi obyek dalam penelitian ini adalah aritmetika pada konsep operasi hitung bilangan bulat dan konsep sistem persamaan linier pada aljabar.

\section{Pembelajaran Matematika}

Menurut Hudoyo (1985), belajar adalah kegiatan yang berlangsung dalam mental seseorang, sehingga terjadi perubahan tingkah laku, di mana perubahan tingkah laku tersebut bergantung kepada pengalaman seseorang. Mengingat proses mental pada suatu individu sulit untuk diamati, sementara pengamatan terhadap proses belajar menjadi penting, maka untuk mengetahui bahwa telah terjadinya proses belajar dengan melihat perubahan tingkah laku dari individu tersebut. Misalnya ketika seorang siswa yang belajar matematika mampu mendemonstrasikan keterampilan matematikanya yang sebelumnya tidak dapat ia lakukan, maka dikatakan bahwa telah terjadi peroses belajar matematika pada diri siswa tersebut.

Seorang Filosof Cina Confucius mengatakan bahwa saya dengar maka saya lupa, saya lihat maka saya ingat, dan saya alami maka saya paham. Bagaimana pula dengan hidup untuk mengikat makna, belajar itu harus mampu memberikan arti bagi yang mempelajarinya, dan arti akan hadir kalau belajar itu dialami. Pembelajaran yang menekankan kepada pemahaman, I do and I understand, sebuah proyek yang didasarkan pada karya Piaget dan Dienes, "the Nuffield Mathematics Project of Great Britain", yang memusatkan pada partisipasi aktif siswa dalam suatu suasana percobaan yang menggunakan bahan peraga konkrit (Marks, Hiaat, dan Neufeld, 1988).

Menurut Ernest (1991) bahwa belajar matematika adalah pertama dan paling utama adalah aktif, dengan siswa belajar melalui permainan, kegiatan, penyelidikan, proyek, diskusi, eksplorasi, dan penemuan.

Belajar didefinisikan sebagai modifikasi terhadap lingkungan melalui pengalaman, pengalaman merupakan guru yang terbaik, belajar dari pengalaman adalah lebih baik daripada sekedar bicara. Karena itu, proses belajar adalah melakukan, bereaksi, mengalami, dan mencoba. Sementara hasil dari belajar adalah semua pencapaian 
oleh pebelajar melalui aktivitasnya. Demikianlah pandangan Witherington dan Burton dalam Dzamarah dan Zain (2006).

Belajar matematika berkenaan dengan mengembangkan kemampuan matematik seperti kemampuan penalaran dan pemecahan masalah itu tidak sekedar membaca atau mendengarkan, tetapi belajar sambil bekerja. Sulit bagi siswa untuk dapat memiliki kemampuan penalaran dan pemecahan masalah matematika, kalau tidak melalui aktivitas atau kegiatan bermatematika. Bagi siswa yang masih dalam tahap berpikir konkrit belajar sambil memanipulasi benda adalah cara belajar matematika yang cocok. Dengan manipulasi tersebut memungkinkan siswa menemukan konsepkonsep atau generalisasi di dalam matematika. Siswa tidak hanya mendengarkan informasi, tetapi mereka juga mengerjakan sesuatu.

\section{Hasil Belajar Matematika}

Jika seseorang belajar matematika, maka setelah belajar kemampuannya akan bertambah terutama kemampuan dalam matematika. Perubahan kemampuan inilah yang dimaksud dengan hasil belajar matematika. Tentu saja hasil yang diharapkan guru adalah hasil yang terbaik. Oleh karena itu, guru harus berusaha dengan sekuat tenaga mengoptimalkan pembelajaran supaya siswa memperoleh hasil belajar matematika yang terbaik. Misalnya sering memberikan latihan soal atau memberikan tes karena dengan adanya latihan mengerjakan soal, siswa akan terbiasa untuk mengaplikasikan materi yang diberikan oleh guru untuk menyelesaikan soalsoal yang ada.

Hukum latihan pada dasarnya menggunakan dasar stimulan dan respon akan memiliki hubungan satu sama lain secara kuat. Jika proses pengulangan sering terjadi akan bersifat otomatis. Seorang anak yang dihadapkan pada suatu persoalan yang sering ditemuinya akan segera melakukan tanggapan secara cepat sesuai dengan pengalamanya pada waktu sebelumnya (Suherman:2005).

Kenyataan membuktikan bahwa dengan adanya pengulangan yang tidak membosankan dan melibatkan siswa dalam proses belajar dapat meningkatkan hasil belajar matematika yang diharapkan oleh guru. Untuk menyatakan bahwa suatu proses belajar mengajar dapat berhasil dapat dilihat dari pemberian tugas dari guru dalam bentuk tes lisan, tes tulisan dan tindakan siswa dalam proses belajar. "Suatu proses belajar mengajar tentang suatu bahan pengajaran dinyatakan berhasil apabila tujuan instruksional dapat tercapai" (syaiful: 2006). Fungsinya untuk memberikan umpan balik kepada guru dalam memperbaiki proses belajar mengajar, indikator keberhasilan dapat dilihat dari evaluasi yang telah diberikan, kedudukan evaluasi dalam belajar sangat penting dan tidak dapat terpisahkan dalam proses belajar. Proses belajar menempatkan evaluasi sebagai penilaian dalam keberhasilan belajar. 
Menurut Ngalim tujuan evaluasi ialah untuk mendapatkan data pembuktian yang akan menunjukan sampai di mana tingkat kemampuan dan keberhasilan siswa dalam pencapaian tujuan-tujuan kurikuler. Di samping itu, juga dapat digunakan oleh guruguru dan para pengawas pendidikan untuk mengukur atau menilai sampai dimana keefektifan pengalaman-pengalaman mengajar, kegiatan-kegiatan belajar, dan metode-metode mengajar yang digunakan (purwanto: 2009).

Dengan demikian guru dapat melihat hasil belajar yang dialami oleh siswa, sampai sejauh mana kemajuan atau kemunduran yang dialami oleh siswa. Evaluasi dan latihan yang diberikan berfungsi sebagai bahan pertimbangan bagi guru dalam melaksanakan proses belajar mengajar, sehingga guru dapat melihat hasil belajar dari siswa. Menurut Gagne dalam buku belajar dan pembelajaran, komponen hasil belajar terdiri dari 5 yaitu:(a) Informasi Verbal : kemampuan untuk mengungkapkan pengetahuan dalam bentuk bahasa, baik lisan maupun tertulis. (b) Kemampuan Intelektual : kecakapan yang berfungsi untuk berhubungan dengan lingkungan hidup, serta mempresentasikan konsep dan lambang. (c) Strategi Kognitif : kemampuan menyalurkan dan mengarahkan aktivitas kognitifnya sendiri. Kemampuan ini meliputi penggunaan konsep dan kaidah dalam pemecahan masalah. (d) Keterampilan Motorik : kemampuan melakukan serangkaian gerak jasmani dalam urusan dan koordinasi, sehingga terwujud otomatisme gerak jasmani. (e) Sikap : kemampuan menerima atau menolak obyek berdasarkan penilaian terhadap obyek tersebut (Dimyati, 2006).

Dengan adanya evaluasi yang diberikan oleh guru dan dengan memperhatikan proses belajar yang sedang dilakukan oleh siswa, maka hasil belajar matematika akan tercapai dengan baik. Jadi belajar yang diarahkan oleh pengalaman dan pemecahan soal matematika akan memudahkan siswa dalam belajar dan hasil belajar diharapkan oleh guru dan orang tua siswa dapat tercapai dengan baik.

\section{Tes Formatif}

Kata tes berasal dari bahasa Prancis kuno yaitu testum yang berarti piring yang dibuat dari tanah untuk menyisihkan logam mulia. Alat ini digunakan untuk memilih logam mulia yang berkualitas. Dari asal kata tes tersebut, maka dapat diartikan bahwa tes adalah suatu alat yang digunakan untuk melihat kualitas sesuatu hal. Seperti pengertian tes dalam buku Suharsimi bahwa tes adalah suatu alat atau prosedur yang sistematis dan objektif untuk memperoleh data-data atau keteranganketerangan yang diinginkan tentang seseorang, dengan cara yang boleh dikatakan tepat dan cepat (Suharsimi, 2009).

Menurut Hopkins dan Antes, tes adalah suatu instrument, alat atau prosedur yang berisikan sejumlah tugas yang harus dijawab oleh siswa yang hasilnya dapat digunakan untuk mengukur suatu ciri tertentu. Melalui jawaban seseorang atas pertanyaan dalam tes diperoleh suatu ukuran (yaitu niali numerik) mengenai 
karakteristik orang tersebut. Menurut Nitko, tes adalah instrument atau suatu prosedur sistematis untuk mengamati dan mendeskripsikan satu atau lebih karakteristik siswa dengan menggunakan skala yang berbentuk angka atau skema klasifikasi tertentu (Jafar, 2008)

Tes yang digunakan untuk mencari umpan balik (feedback) guna memperbaiki proses belajar mengajar bagi guru maupun siswa disebut tes formatif. Norman dalam bukunya menuliskan : Formative evaluation is used to monitor learning progress during instruction and to provide continuous feedback to both pupil and techer concerning learning successes and failures (Norman, 1985).

Tes formaitif biasanya dilakukan pada akhir proses belajar mengajar, tapi bisa juga dilakukan pada saat proses belajar mengajar berlansung. Tes yang diberikan guru pada saat proses belajar mengajar bertujuan untuk mengecek atau mendapatkan informasi apakah siswa telah memahami apa yang diterangkan guru. Jadi guru bisa merubah dan memperbaiki cara belajarnya apabila banyak yang belum mengerti.

Tes formatif berfungsi untuk memperbaiki proses belajar mengajar. Jadi tes formatif ini dilakukan untuk menilai hasil belajar dari tiap satuan pelajaran yang dilakukan diakhir pelajaran. Sebab perbaikan atas proses belajar dan mengajar harus dilakukan secara sistematis dan bertahap.

Dalam menyususn soal tes formatif, tingkat kesukaran dan daya pembeda tiap soal tes tidak terlalu penting.Tes formatif merupakan salah satu tes yang perlu guru berikan pada siswa yng diajarnya, karena tes formatif memiliki beberapa kelebihan yang akan sangat bermanfaat demi keberhasilan pengajaran. Beberpa kelebihan tes formatif diantaranya adalah:

a) Dapat langsung melihat pemahaman siswa di setiap satuan pembelajaran

b) Bisa dijadikan tolak ukur ketercapaian tujuan instruksinoal khusus

c) Melihat dan memperbaiki kelemahan dan keunggulan yang ada pada siswa dan juga guru

d) Memberikan umpan balik pada siswa dan guru

Namun disamping memiliki kelebihan seperti yang disebutkan di atas, tes formatif pun memiliki beberapapa kekurangan. Bebapa kekurangan pada tes formatif diantaranya adalah waktu yang tersedia hanya sedikit, memerlukan banyak biaya dan menyita waktu guru untuk membuat instrument dan memeriksa jawaban siswa

Agar tes formatif dapat berfungsi sebagaimana mestinya, maka cara pengelolaan hasil tes formatif haruslah tepat. Cara pengolahan tes formatif adalah :

a) Menghitung persentase siswa yang gagal dalam setiap butir soal, untuk mengetahui sejauh mana tujuan pengajaran dengan soal telah dicapai oleh kelas.

b) Menghitung persentase penguasaan kelas atas bahan yang telah diajarkan, untuk mengetahui kriteria keberhasilan belajar telah tercapai. 
c) Menghitung persentase jawaban yang benar setiap siswa dalam keseluruhan tes, untuk mengetahui penguasaan siswa atas bahan yang telah diajarkan (Suharsimi, 2009)

\section{Tes Pilihan Ganda}

Dalam bukunya, Norman menuliskan tentang tes bentuk pilihan ganda sebagai berikut: The multiple-choice item consists of a stem, which present a situation, and several alternatives (options or choices) which provide possible solutions to the problem. The stem may be a question or an incomplete statement. The alternatives include the correct answer and several plausible wrong answers called distracters. The function of the latter is to distract those students who are uncertain of the answer (Norman, 1993).

Dari pengertian yang disampaikan Norman di atas, tes bentuk pilihan ganda itu teridiri dari pernyataan pengantar dan pernyataan tidak lengkap serta beberapa pilihan jawaban. Pilihan jawaban biasanya terdiri dari empat atau lima pilihan. Dari beberapa pilihan yang ada, hanya ada satu jawaban yang benar dan jawaban lainnya sebagai pengecoh.

Dalam mengukur hasil belajar siswa, tes bentuk pilihan yang sering digunakan terdiri dari beberapa model, diantaranya adalah :

a) Melengkapi pilihan

Bentuk soal ini terdiri atas kalimat pokok yang berupa pernyataan belum lengkap diikuti oleh empat atau lima kemungkinan jawaban yang dapat melengkapi pernyataan tersebut tapi hanya ada satu jawaban yang benar.

b) Analisis hubungan antar hal

Soal berbentuk kalimat pernyataan yang didikuti oleh satu kalimat alasan. Dengan pilihan jawaban mengenai kebenaran dan hubungan pernyataan dan alasan.

c) Analisis kasus

Soal yang berbentuk simulasi keadaan nyata baik berupa cerita, uraian kejadian, situasi, proses dan hasil percobaan ataupun penelitian yang ada hubungannya dengan mata pelajaran.

d) Melengkapi berganda (asosiasi pilihan ganda)

Bentuk soal asosiasi piliahan gansa adalah soal yang berbentuk pernyataan yang tidak lengkap tetapi kemungkinan jawabannya satu, dua, tiga, atau empat.

e) Analisis diagram

Bentuk soal analsisis diagram sama seperti bentuk soal melengkapi pilihan tetapi dalam bentuk soal analisis diagram dilengkapi dengan gambar, diagram atau grafik. 
Setiap bentuk soal tertentu pasti memiliki kelebihan dan kelemahan. Begitupun dengan bentuk soal pilihan ganda. Kelebihan bentuk soal pilihan ganda diantaranya dapat diskor dengan mudah, cepat dan objektif; mencakup materi yang luas atau banyak, cocok untuk jumlah peserta tes yang banyak, hasil dapat segera diumumkan.

Adapun kelemahan bentuk tes pilihan ganda diantaranya membutuhkan waktu yang lama untuk membuat soal, sulit membuat pengecoh, siswa memiliki peluang yang banyak untuk menebak dan menanyakan jawaban pada temannya. Untuk mengatsi kelemahan tes pilihan ganda yang terakhir, maka peneliti dalam penelitian ini mencoba untuk memberikan reward dan punishment score.

\section{Tes Assosiasi Pilihan Ganda}

Tes obyektif yang juga dikenal dengan istilah tes jawaban pendek (short answer test) adalah salah satu jenis tes hasil belajar yang terdiri dari butir-butir soal yang dapat dijawab oleh siswa dengan jalan memilih salah satu atau lebih diantara beberapa kemungkinan jawaban yang telah dipasangkan pada masing-masing butir soal atau dengan jalan menuliskan atau mengisikan jawabannya berupa kata-kata atau simbol-simbol tertentu pada tempat atau ruang yang telah disediakan untuk masing-masing butir. Ada juga yang mengemukakan bahwa tes pilihan ganda adalah tes yang butir-butir soalnya selalu terdiri dari dua komponen utama yaitu bagian yang menghadapkan siswa kepada satu pernyataan langsung atau sebuah pernyataan tak lengkap dan dua atau lebih pilihan jawaban yang satu lebih benar dan sisanya salah atau disebut dengan pengecoh.

The multiple-choice item requires the pupil to recognize which of several suggested responses is the best or the correct way to answer a question or complete a statement. Multiple choice question are found in several patterns. Probably the most common pattern is the use of a stem, which sets the question, followed by several alternative statements, one of which is assumed to be the best answer (Wrighstone: 1956)

Penjelasan dari uraian di atas bahwa jenis tes pilihan ganda sangat menuntut siswa untuk menyelesaikan sebuah pertanyaan dengan cara menjawab pertanyaan yang dianggap paling benar atau melengkapi pernyataan tersebut. Pertanyaan tipe pilihan ganda ini dapat ditemukan dalam beberapa pola. Mungkin pola yang paling umum adalah pola batang atau asosiasi, yang menetapkan pertanyaan, diikuti oleh beberapa pernyataan atau jawaban alternatif, yang salah satunya dianggap paling benar. Pada Hakikatnya bentuk soal asosiasi pilihan ganda kemungkinan yang benar satu, dua, tiga, atau empat (Chabib, 2003). Adapun jenis tes kombinasi, yaitu jenis tes pilihan ganda yang tiap alternatif jawaban terdiri dari beberapa alternatif yang membentuk satu pengertian/jawaban. Apabila kombinasinya diubah akan mengubah pengertian, sehingga menyebabkan jawaban menjadi salah. Jenis ini sering disebut dengan jenis asosiasi pilihan ganda. 
Jenis tes asosiasi sering disebut tes identifikasi, karena pada proses evaluasi para siswa diminta menghubungkan atau mengidentifikasi satu konsep dengan konsep lainnya (Sukardi, 2010). Jenis asosiasi memang memerlukan ingatan fakta dari para siswa dengan cara yang tepat, di samping itu jenis tes asosiasi sangat cocok untuk mengungkap kemampuan siswa dalam menentukan konsep yang memiliki hubungan, sebab dan akibat.

Tes formatif obyektif bentuk multiple choice item model asosiasi dengan lima atau empat pilihan ini terdiri dari lima atau empat judul /istilah/pengertian, yang diberi tanda huruf abjad di depannya dan diikuti oleh beberapa pernyataan yang diberi nomor urut didepannya. Untuk tiap pernyataan tersebut siswa diminta memilih salah satu judul/istilah/pengertian yang berhuruf abjad, yang menurut keyakinan siswa adalah paling cocok atau paling benar (Anas: 2003).

Salah satu contoh item asosiasi pilihan ganda

Petunjuk : pilihlah salah satu jawaban yang dianggap paling benar

(a) jika pertanyaan (1), (2), dan (3) benar.

(b) jika pertanyaan (1) dan (3) saja yang benar.

(c) jika pertanyaan (2) dan (4) saja yang benar.

(d) jika hanya (4) saja yang benar.

(e) jika semuanya benar.

Contoh soal asosiasi pilihan ganda:

Manakah dari bangun di bawah ini yang termasuk bangun ruang sisi lengkung ?

(1) tabung

(2) kerucut

(3) bola

(4) kubus

Jawaban : A , karena yang benar adalah (1), (2), dan (3).

Berdasarkan beberapa uraian di atas bahwa tes formatif bentuk asosiasi pilihan ganda adalah salah satu jenis tes hasil belajar yang terdiri dari butir-butir soal yang dapat dijawab oleh siswa dengan cara memilih salah satu atau lebih di antara beberapa kemungkinan jawaban yang telah dipasangkan pada masing-masing pertanyaannya yang terdiri dari lima atau empat judul/istilah/pengertian, yang diberi tanda huruf abjad di depannya dan diikuti oleh beberapa pernyataan yang diberi nomor urut didepannya. Untuk tiap pernyataan tersebut siswa diminta memilih salah satu judul/istilah/pengertian yang berhuruf abjad, yang menurut keyakinan siswa adalah paling cocok atau paling benar. 


\section{Score}

Dalam kamus lengkap Inggris-Indonesia score artinya adalah skor, angka, atau biji. Dalam buku Sudijono disebutkan tentang pengertian skor sebagai hasil pekerjaan menyekor (= memberikan angka) yang diperoleh dengan jalan menjumlahkan angka-angka bagi setiap butir item yang oleh testee telah dijawab dengan betul, dengan memperhitungkan bobot jawaban betulnya (Anas, 1996)

Jadi skor merupakan angka yang diberikan kepada siswa setelah siswa tersebut menjawab soal yang diberikan padanya. Tentu saja angka yang diberikan sesuai dengan ketentuan yang telah ditentukan sebelumnya oleh guru sebagai tester.

Dalam memberikan skor seabiknya seorang guru menggunakan alat bantu. Alat bantu yang dapat digunakan dalam memberikan skor adalah sebagai berikut :

a) Kunci jawaban, yaitu alat untuk membantu menentukan jawaban yang benar

b) Kunci scoring, yaitu alat untuk membantu menyeleksi jawaban yang benar dan yang salah

c) Pedoman penilaian, yaitu alat untuk membantu menentukan angka

Pemberian skor pada tes objektif biasanya menggunakan rumus correction for guessing atau disebut juga sistem denda. Misalnya pada soal tes pilihan ganda diberi skor maksimal 1 (satu). Apabila siswa menjawab betul satu soal, maka diberi skor 1 dan jika siswa itu menjawab satu soal salah, maka diberikan skor 0 (nol). Namun pemberian skor dengan sistem denda dalam penelitian ini yaitu siswa yang menjawab soal denga tepat mendapat skor 4, yang menjawab soal tidak tepat mendapat skor -1 , dan yang tidak menjawab tidak mendapatkan skor atau dengan kata lain skonya 0 (nol). Penskoran seperti ini merujuk pada ketentuan penskoran tes penerimaan mahasiswa baru di perguruan tinggi negeri.

\section{Reward}

Menurut bahasa, kata reward dalam kamus inggris Indonesia berarti ganjaran. Sedangkan dalam kamus lengkap psikologi, reward meupakan sembarang perangsang, situasi atau pernyataan lisan yang bisa menghasilkan kepuasan atau menambah kemungkinan suatu perbuatan yang telah dipelajari (Chaplin, 2004).

Reward merupakan reinforcement yaitu sebuah penguatan positif. Dalam teori operant conditioning B.F. Skiner disebutkan bahwa conditioning yang memperkuat hubungan stimulus respon yang menjadi pembentuk tingkah laku itu adalah sesuatu yang "operant" atau "reinforcement" yaitu sesuatu stimulus yang dapat memberikan penguatan, seperti hadiah sebagai penguat positif (reward) dan hukuman sebagai penguat negatif (punishment).

Hamchek dalam bukunya menyebutkan " Reward arouse good feeling about our selves, our work, and usually about those doing the rewarding”(Hamchek, 1990). 
Dari pengertian yang diungkapkan Hamchek tersebut ternya reward bisa membangkitkan atau membangun perasaan baik siswa dalam belajar. Jadi reward bisa meningkatkan reaksi diamana reward itu diberikan pada reaksi tersebut. Sebagai contoh, seorang siswa diminta mengerjakan soal matematika tentang sistem persamaan linear dua variabel, kemudian siswa itu mampu menjawab dengan benar dan guru memberikan dia sebuah pujian atau penghargaan lainnya. Maka siswa itu akan bersemangat untuk bisa mengerjakan soal-soal lain yang diberikan oleh gurunya sehingga dia akan giat belajar (Hamchek, 1990)

Jadi reward adalah penghargaan atau hadiah yang diberikan oleh seseorang (guru) kepada seseorang atau kelompok tertentu (siswa). Reward diberikan kepada siswa yang berhasil (mampu mengerjakan soal dengan baik). Reward yang diberikan itu merupakan sesuatu yang menyenangkan atau yang digemari oleh siswa, bisa berupa benda konkrit atau abstrak, misalnya pujian, perhatian, penghargaan, dan lain-lain.

Macam-macam reward, yaitu :

a) Pujian, merupakan reward yang berbentuk kata-kata atau kalimat seperti baik, bagus, bagus sekali, selamat dan pertahankan hasil belajarmu, dan sebagainya.

b) Penghormatan, merupakan reward yang berupa penobatan dan pemberian kekuasaan untuk melakukan sesuatu.

c) Hadiah, merupakan reward berbentuk pemberian suatu barang tertentu, terutama barang yang disukai oleh siswa yang mendapatkan reward tersebut.

d) Penghargaan, merupakan reward simbolis yang tidak dinilai dari segi harganya melainkan dari segi kesan dan kenang-kenangannya.

Dalam penelitian ini yang dimaksud dengan reward score adalah skor lebih yang diberikan kepada siswa yang bisa menjawab soal atau tes yang diberikan sebagai suatu penghagaan. Pemberian angka atau skor ini dimakasudkan agar siswa bisa lebih semangat atau termotivasi utuk belajar, karena biasanya angka merupakan motivasi yang kuat bagi siswa. Oleh karena itu, pemberian angka atau skor disebut reward karena dapat membangkitkan motivasi siswa.

\section{Punishment}

Dalam kamus bahasa Inggris-Indonesia, punishment adalah hukuman. Hukuman dalam pendidikan harus bernilai positif dan dapat meningkatkan moral dan motivasi siswa menjadi lebih baik. Jadi hukuman disini adalah untuk melemahkan dan menghentikan tingkah laku negatif yang membuat siswa tidak berprestasi seperti yang diharapkan.

Dalam kamus lengkap psikologi, punishment adalah: 1) penderitaan atau siksaan rasa sakit, atau rasa tidak senang pada seorang subjek, karena kegagalan dalam menyesuaikan diri terhadap suatu rangkaian perbuatan yang sudah ditentukan terlebih dahulu dalam satu percobaan, 2) Suatu perangsang dengan valensi negative, 
atau satu perangsang yang mampu menimbulkan kesakitan atau ketidaksenangan, 3) Pembebanan satu periode pengurungan atau penahanan pada seorang pelanggar yang sah (Chaplin, 2004).

Sesuai pengertian di atas, punishment itu diberikan kepada seseorang yang tidak bisa mengikuti aturan yang telah ditentukan sebelumnya. Siswa yang melanggar aturan harus diberikan hukuman. Seringkali siswa melakukan hal-hal yang tidak diharapkan atau tidak sesuai aturan pada saat melaksanakan ujian, seperti mencontek, bekerjasama, dan menebak jawaban. Untuk mengatasi hal itu, maka perlu diberikan suatu hukuman. Dalam penelitian ini, hukuman bagi siswa yang salah menjawab soal,diberikan skor minus, yaitu -1 .

Pemberian skor minus kepada siswa merupakan sesuatu hal yang tidak menyenangkan bagi mereka. Pemberian hal yang tidak menyenangkan kepada seseorang yang melakukan kesalahan atau menghilangkan hal yang menyenangkan bagi seseorang yang melakukan kesalahn bisa dikatakan sebagai punishment. Hal ini sesuai dengan yang dikatakan Kazdin dalam bukunya Stephen bahwa punishment adalah " the presentation of an aversive event or the removal of positive event following a response that decreases the frequency of that response"(Stephen: 2000)

Pemberian punishment pada siswa harus dalam tingkat kewajaran karena bila berlebihan akan membuat siswa menjauh dan takut untuk belajar matematika. Oleh karena itu pemberian punishment haruslah memenuhi syarat-syarat berikut : pemberian hukuman harus dalam cinta dan kasih sayang, didasarkan pada alasan "keharusan", bisa menimbulkan kesan di hati siswa, diikuti pemberian maaf dan harapan serta kepercayaan, mengandung makna edukasi.

Selain syarat yang disebutkan di atas, pemberian punishment sebaiknya berdasarkan kesepakatan antara guru dan siswa atau dengan kata lain ada perjanjian dari kedua belah pihak. Misalnya seperti yang akan dilakukan dalam penelitian ini, memberikan skor minus kepada siswa yang menjawab salah dalam menjawab soal yang diberikan. Pemberian skor minus ini sebelumnya harus disampaikan telebih dahulu pada siswa supaya siswa tahu konsekuensi jika dia menjawab soal dengan salah.

Pemberian punishment yang tepat dan tidak berlebihan akan memberikan damapak positif, diantaranya adalah :

a) Akan tercipta suasana belajar yang nyaman dan tentram, sehingga siswa akan berkonsentrasi pada saat belajar dan hasil belajar siswa akan meningkat.

b) Siswa akan memiliki sikap yang baik pada guru, teman dan peraturan dengan tujuan untuk memproleh hasil belajar yang baik.

c) Membentuk kepribadian siswa yang disiplin dalam memperoleh hasil belajar yang baik

d) Mengurangi kebiasaan buruk siswa 
Beberapa guru terkadang hanya sekedar memberikan hukuman pada siswanya tanpa memperhitungkan baik buruknya hukuman yang diberikan pada siswa tersebut. Pemberian punishment yang tidak tepat akan berdampak negative seperti siswa bisa berontak jika tidak merasa nyaman dengan hukuman yang diberikan terasa berlebihan, sehingga hasil belajar siswa akan menurun dan bisa menimbulkan rasa tidak suka pada diri siswa terhadap guru yang memberikan hukuman, sehingga siswa malas untuk belajar dan hasil belajarnya pasti akan jelek.

Dalam hal ini pemberian punishment dimaksudkan untuk memperbaiki dan menyadarkan siswa pada kesalahan yang diperbuatnya pada saat menjawab soal-soal yang diberikan padanya, sehingga siswa berjanji pada dirinya sendiri tidak akan mengulangi kesalahan yang serupa. Punishment score berupa pengurangan atau pemberian nilai minus kepada siswa yang salah dalam menjawab soal atau tes yang diberikan. Hal ini dimaksudkan agar siswa lebih hati-hati dalam menjawab suatu permasalahan yang ada, tidak hanya asal tebak dalam memilih jawaban.

\section{Metodologi Penelitian}

Penelitian ini menggunakan model Penelitian dan Pengembangan (Research and Develompent), yang di dalamnya juga akan melibatkan metode kuantitatif dan kualitatif. Kuantitatif digunakan berkenaan dengan ujicoba tes assosiasi pilihan ganda dengan reward dan punishment score dan pengujian lebih lanjut kepada siswa berdasarkan instrumen hasil belajar siswa, sedangkan lembar observasi aktivitas siswa, respon siswa, tinjauan dan validasi ahli dianalisis secara kualitatif.

Penelitian ini mengukur dan menelaah pengaruh bentuk tes formatif assosiasi pilihan ganda dengan reward dan punishment score dalam pembelajaran matematika siswa SMA DKI Jakarta. Sampel penelitian ini di SMA N 64 Jakarta Timur dan SMA N 16 Jakarta Barat.

Data penelitian pengembangan dianalisis secara deskriptif dan inferensial. Analisis deskriptif dilakukan terhadap data yang diperoleh selama proses studi pendahuluan, perancangan, pembuatan dan pengembangan tes formatif assosiasi pilihan ganda dengan reeward dan punishment score matematika, maupun berkenaan dengan instrumen-instrumen non tes. Sedangkan tes hasil belajar matematika siswa dianalisis secara inferensial yaitu dengan menggunakan uji normalitas, uji homogenitas dan uji-t dengan menggunakan SPSS for Windows, untuk dilihat pengaruh penggunaan bentuk tes assosiasi pilihan ganda dengan reeward dan punishment score terhadap hasil belajar matematika siswa SMA. 


\section{Hasil Penelitian}

Sebelum melakukan pengujian hipotesis, terlebih dahulu dilakukan uji persyaratan normalitas dan uji homogenitas.

\section{Uji Normalitas}

Pengujian normalitas data hasil belajar matematika siswa secara dilakukan dengan menggunakan uji Shapiro-Wilk, dengan menggunakan SPSS 16 for windows. Hasil perhitungan uji normalitas hasil belajar kelas eksperimen dapat dilihat dalam Tabel 1 berikut:

\section{Tabel 1}

Hasil Uji Normalitas

\begin{tabular}{|ll|r|r|r|r|r|r|}
\hline \multirow{2}{*}{} & \multirow{2}{*}{ Kelas } & \multicolumn{4}{|c|}{ Kolmogorov-Smirnov $^{\mathrm{a}}$} & \multicolumn{3}{|c|}{ Shapiro-Wilk } \\
\cline { 2 - 8 } & Statistic & \multicolumn{1}{c|}{ df } & \multicolumn{1}{c|}{ Sig. } & Statistic & \multicolumn{1}{c|}{ df } & \multicolumn{1}{c|}{ Sig. } \\
\hline Pembelajaran & Eksperimen & .167 & 40 & .057 & .941 & 40 & .139 \\
& Kontrol & .179 & 40 & .102 & .955 & 40 & .109 \\
\hline
\end{tabular}

a. Lilliefors Significance Correction

Dari Tabel 1 diperoleh $p$-value (Asymp Sig) kelas eksperimen adalah 0,139>0,05= $\alpha$, dan p-value (Asymp Sig) kelas kontrol adalah 0,109 $>0,05=\alpha$, maka $\mathrm{H}_{0}$ diterima. Sehingga dapat disimpulkan bahwa hasil belajar matematika siswa kelas eksperimen dan siswa kelas kontrol berdistribusi normal pada taraf signifikansi $\alpha=$ 0,05 .

\section{Uji Homogenitas}

Pengujian homogenitas data kemampuan analogi matematis siswa secara keseluruhan dilakukan dengan menggunakan uji Levene. Hasil perhitungannya dapat dilihat dalam Tabel 2 berikut:

Tabel 2

\section{Hasil Uji Homogenitas}

Test of Homogeneity of Variances

Pembelajaran

\begin{tabular}{|c|c|c|c|}
\hline Levene Statistic & df1 & df 2 & Sig. \\
\hline .369 & 1 & 78 & .545 \\
\hline
\end{tabular}

Dari Tabel 2 untuk menguji homogenitas varians skor hasil belajar matematika terlihat nilai Lavene Statistic $(\mathrm{F})$ adalah sebesar 0,369dengan nilai signifikansi sebesar 0,545. Nilai signifikansi tersebut lebih dari taraf signifikansi $\alpha=0,05$ sehingga dapat disimpulkan bahwa $\mathrm{H}_{0}$ yang menyatakan veriansi populasi kedua 
kelompok data adalah sama diterima. Artinya, kedua kelompok data skor hasil belajar matematika siswa memiliki varians yang homogen.

\section{Uji Hipotesis}

Hipotesis penelitian yang telah dirumuskan menyatakan bahwa terdapat pengaruh pemberian tes formatif bentuk asosiasi pilihan ganda dengan reward score terhadap hasil belajar matematika siswa. Hipotesis yang diajukan di uji melalui $t$-test. Dengan menggunakan bantuan program SPSS 16 for Windows, berikut hasil hasil pengujian uji $t$ :

Tabel 3

Hasil Uji Hipotesis

Independent Samples Test

\begin{tabular}{|c|c|c|c|c|c|c|}
\hline & \multicolumn{2}{|c|}{$\begin{array}{c}\text { Levene's Test for Equality } \\
\text { of Variances }\end{array}$} & \multicolumn{3}{|c|}{$\begin{array}{l}\text { t-test for Equality of } \\
\text { Means }\end{array}$} \\
\hline & & F & Sig. & $\mathrm{t}$ & $\mathrm{df}$ & $\begin{array}{l}\text { Sig. (2- } \\
\text { tailed) }\end{array}$ \\
\hline Rembelajaran & $\begin{array}{l}\text { Equal variances } \\
\text { assumed }\end{array}$ & \multirow[t]{2}{*}{.369} & \multirow[t]{2}{*}{.545} & \multirow{2}{*}{$\begin{array}{l}2.195 \\
2.195\end{array} \mid$} & \multirow{2}{*}{$\begin{array}{r}78 \\
77.468\end{array}$} & \multirow{2}{*}{$\begin{array}{l}.031 \\
.031\end{array}$} \\
\hline & $\begin{array}{l}\text { Equal variances not } \\
\text { assumed }\end{array}$ & & & & & \\
\hline
\end{tabular}

Dari Tabel 3 diperoleh $p$-value (Asymp Sig) kelas eksperimen adalah 0,355 > 0,05 = $\alpha$, dan $p$-value (Asymp Sig) kelas kontrol adalah $0,031<0,05=\alpha$, maka hipotesis $\mathrm{H}_{0}$ ditolak. Hal ini menunjukkan adanya pengaruh pemberian tes formatif bentuk asosiasi pilihan ganda dengan reward score terhadap hasil belajar matematika siswa pada pokok bahasan turunan fungsi.

Hasil pengujian yang membuktikan bahwa adanya pengaruh pemberian tes formatif bentuk asosiasi pilihan ganda dengan reward score terhadap hasil belajar matematika siswa bukanlah suatu kebetulan, tetapi karena adanya perlakuan yang diberikan kepada siswa. Pada kelas eksperimen, siswa diberikan perlakuan berupa pemberian tes formatif bentuk asosiasi pilihan ganda di setiap akhir pembelajaran seperti terlihat dalam Gambar 1
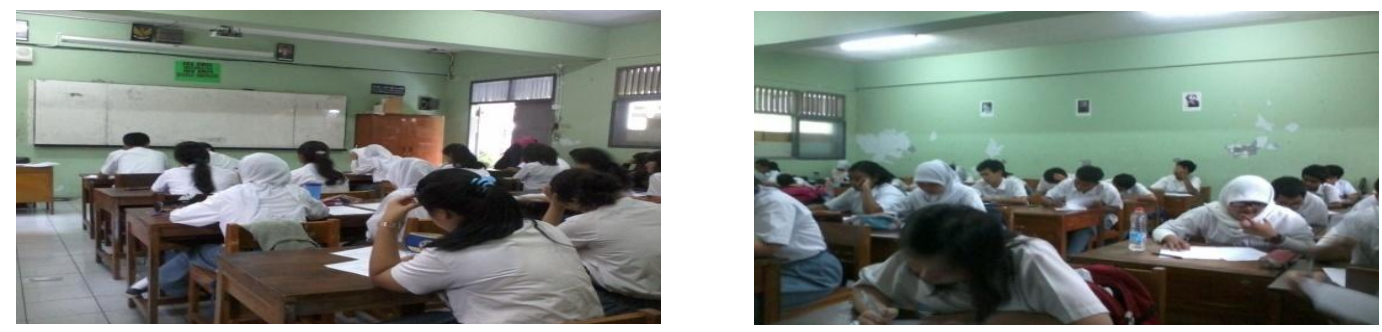
Dari Gambar 1 (a) dan (b) terlihat bahwa siswa bersungguh-sungguh dalam mengerjakan tes formatif . Hal itu dikarenakan setiap siswa yang dapat menyelesaikan soal tes formatif dengan benar akan mendapatkan reward score sebanyak 2 (dua) poin. Pada saat proses kegiatan belajar mengajar di kelas eksperimen, siswa laki-laki lebih aktif daripada siswa perempuannya dalam mengerjakan tes formatif maupun latihan soal yang sebelumnya diberikan oleh guru. Mereka sering bertanya apabila ada hal yang belum dimengerti. Motivasi belajar siswa di kelas eksperimen cukup bagus, hal itu terlihat dari perolehan skor tes formatif yang diberikan di setiap akhir subpokok bahasan materi turunan fungsi yang terlihat pada Gambar 2 berikut ini:

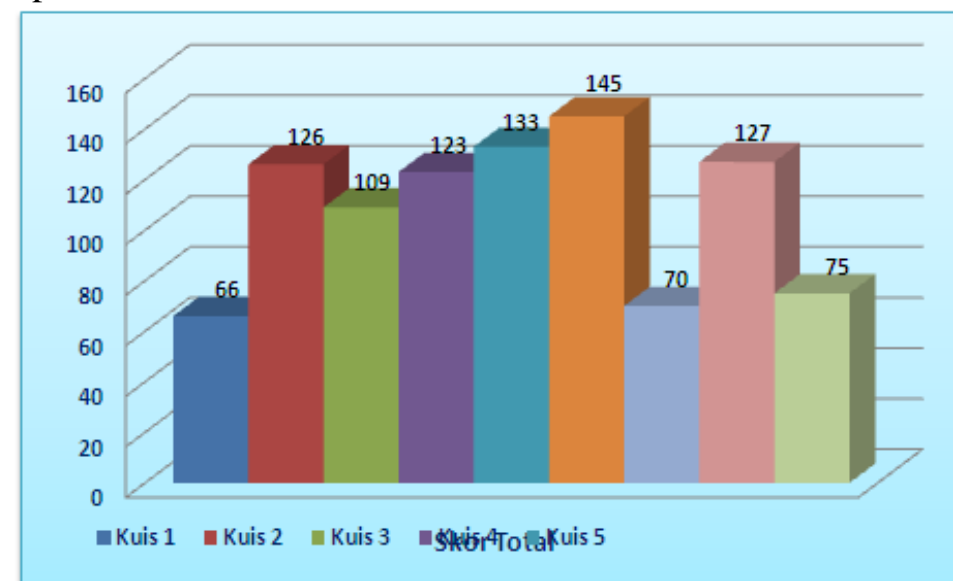

Gambar 2

\section{Perolehan Skor Total Kuis Tiap Subpokok Materi Turunan Fungsi}

Dari Gambar 2 terlihat bahwa tes formatif 1 hanya memperoleh skor total 65 atau 41,667\% dari skor ideal. Hal itu dikarenakan banyak siswa yang tidak teliti dalam menentukan jawaban. Tes formatif 2 memperoleh skor total 126 atau mencapai $80,770 \%$ dari skor ideal. Skor total tes formatif 2 lebih baik dari tes formatif 1 karena subpokok bahasan pada materi 2 lebih mudah dimengerti sehingga siswa dapat memahami lebih baik. Tes formatif 3 memperoleh skor total 109 atau $73,649 \%$ dari skor ideal dan mengalami penurunan skor dari tes formatif 2 karena jam pelajaran matematika digunakan oleh mata pelajaran sebelumnya kurang lebih 15 menit sehingga waktu untuk mengerjakan tes formatif berkurang. Tes formatif 4 memperoleh skor total 123 atau $78,846 \%$ dari skor ideal. Tes formatif 5 memperoleh skor total 133 atau 83,125\% dari skor ideal. Tes formatif 6 memperoleh skor total 145 atau mencapai $97,973 \%$ dari skor ideal. Tes formatif 7 hanya memperoleh skor total 70 atau $44,872 \%$ dari skor ideal. Tes formatif 8 memperoleh skor total 127 atau 79,375\% dari skor ideal. Tes formatif terakhir, tes formatif 9 memperoleh skor total 75 atau hanya $46,875 \%$. Tes formatif 3 sampai dengan tes formatif 6 mengalami peningkatan yang cukup signifikan. Hal tersebut dapat terlihat dari selisih tes formatif 3 dan tes formatif 4 tidak berbeda jauh 
dengan selisih tes formatif 4 dan tes formatif 5 (lihat Grafik 4.4). Tetapi pada tes formatif 7 mengalami penurunan drastis karena banyak siswa yang sudah tidak konsentrasi mengerjakan tes formatif karena suasana di kelas sudah tidak nyaman dan tidak kondusif. Tes formatif 8 mengalami peningkatan tetapi pada tes formatif 9 mengalami penurunan lagi karena banyak siswa yang mengeluhkan masih belum paham materi yang diajarkan untuk tes formatif 9. Dari Grafik 4.4 juga dapat terlihat bahwa perolehan skor tertinggi berada di tes formatif 6 yang mencapai skor total 145 atau 97,973\% dari skor ideal dan perolehan skor terendah berada di tes formatif 1 yang hanya mencapai skor total 66 atau 41,667\% dari skor ideal.

Sedangkan pada kelas kontrol, tidak diberikan tes formatif bentuk asosiasi pilihan ganda. Proses pembelajaran yang dilakukan di kelas kontrol adalah proses pembelajaran yang biasa dilakukan oleh guru kelas sehari-hari. Setelah kedua kelas diberikan perlakuan, guru memberikan tes hasil belajar matematika kepada kedua kelas tersebut. Didapatkan skor rata-rata hasil belajar matematika seperti pada Grafik 3 sebagai berikut:

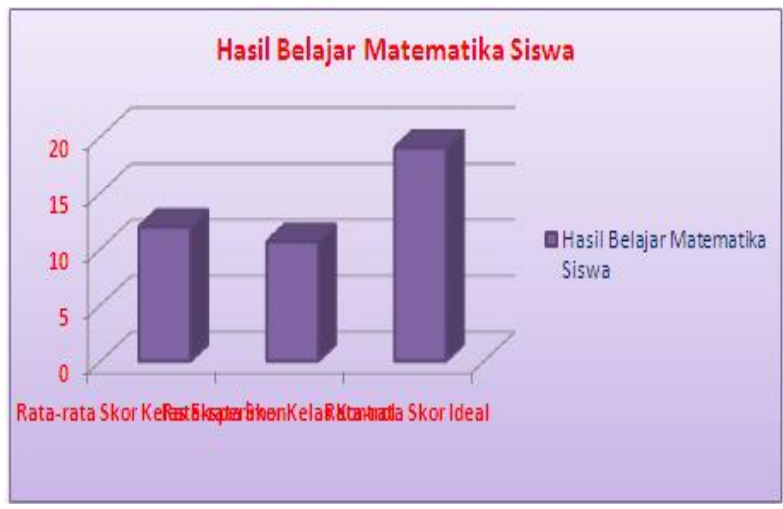

Grafik 3

Rata-rata skor hasil belajar matematika

Dari Grafik 3 dapat terlihat bahwa rata-rata skor hasil belajar matematika siswa kelas eksperimen lebih tinggi dibandingkan rata-rata skor hasil belajar matematika siswa kelas kontrol. Untuk lebih jelas, disajikan rekapitulasi rata-rata skor hasil belajar matematika siswa dalam bentuk Tabel 4.9 sebagai berikut:

Tabel 4.9

Rekapitulasi rata-rata skor hasil belajar matematika

\begin{tabular}{|c|r|c|}
\hline $\begin{array}{c}\text { Rata-rata Skor } \\
\text { Kelas Eksperimen }\end{array}$ & $\begin{array}{r}\text { Rata-rata Skor } \\
\text { Kelas Kontrol }\end{array}$ & Skor Ideal \\
\hline 11,950 & 10,650 & 19 \\
\hline
\end{tabular}


Rata-rata skor ideal hasil belajar matematika adalah 19. Rata-rata skor hasil belajar matematika siswa kelas eksperimen adalah 11,950 atau $62,895 \%$ sedangkan rata-rata skor hasil belajar matematika siswa kelas kontrol adalah 10,650 atau 56,053\%. Perbedaan rata-rata skor hasil belajar matematika siswa kelas eksperimen dan kontrol yaitu 1,300 atau $6,842 \%$.

\section{SIMPULAN, IMPLIKASI DAN SARAN}

\section{Simpulan}

Berdasarkan data penelitian dan hasil analisis data dapat disimpulkan:

a. Dari data eksperimen dapat disimpulkan terdapat pengaruh penggunaan bentuk tes formatif assosiasi pilihan ganda dengan reward dan punishment score pada pembelajaran matematika SMA.

b. Diperoleh bentuk tes formatif assosiasi pilihan ganda dengan reward dan punishment score yang cocok dengan pembelajaran matematika SMA.

c. Tes formatif assosiasi pilihan ganda dengan reward dan punishment score yang cocok dengan pembelajaran matematika SMA efektif diterapkan dalam proses pembelajaran terutama dalam evaluasi pembelajaran.

\section{Saran}

Berdasarkan hasil penelitian yang telah diperoleh, penulis memberikan beberapa saran sebagai berikut :

a. Guru dapat mnerapkan tes formatif assosiasi pilihan ganda dengan reward dan punishment score yang cocok dengan pembelajaran matematika SMA efektif diterapkan dalam proses pembelajaran terutama dalam evaluasi pembelajaran.

b. Hendaknya guru melakukan analisis kesulitan materi sebelum membuat Tes formatif assosiasi pilihan ganda dengan reward dan punishment score.

c. Guru sebagai pendidik dalam proses belajar mengajar di harapkan selalu meningkatkan kualitas pembelajarannya yang telah ada, salah satunya dengan memberikan kuis guna mengetahui penguasaan materi yang dicapai oleh siswa.

d. Diharapkan bentuk kuis tersebut disajikan dalam bentuk instrumen yang cukup kompleks dalam menjawabnya, misalnya berbentuk asosiasi pilihan ganda. Selain itu berikan reward score pada kuis asosiasi pilihan ganda tersebut agar siswa lebih termotivasi dan bersungguh-sungguh dalam mengerjakannya.

e. Dalam proses belajar mengajar, guru harus mampu menciptakan pembelajaran yang efektif dan melakukan evaluasi agar siswa dapat menerima pelajaran dengan baik sehingga hasil belajar siswa dapat meningkat.

Mengingat hasil penelitian ini masih sangat terbatas, apa yang didapat dari hasil penelitian ini bukan merupakan hasil akhir, tentu segala keterbatasan yang ada dalam penelitian ini dapat dijadikan bahan referensi untuk penelitian lebih lanjut. 


\section{DAFTAR PUSTAKA}

Anitah, W.S., Manoy, J.T., dan Susanah. (2007). Strategi Pembelajaran Matematika. Jakarta: UT Depdiknas.

Arikunto, S. (2006). Prosedur Penelitian Suatu Pendekatan Praktek. Jakarta: Rineka Cipta. . (2009). Dasar-Dasar Evaluasi Pendidikan. Jakarta: Bumi Aksara.

Asyhadi, A. (2005). Pengenalan Laboratorium Matematika di Sekolah. IHT Media Bagi Staf LPMP Pengelola Laboratorium Matematika Tanggal 5 s.d. 11 September 2005 di PPPG Matematika Yogyakarta.

Bell, F. H. (1978). Teaching and Learning Mathematics (the secondary schools). USA: Wm. C. Brown Company Publisher.

Chaplin, J. P. 1968. Kamus Lengkap Psikologi. Jakarta : Raja Grafindo Persada.

Djamarah, S. B dan Zain, A. (2006). Strategi Belajar Mengajar. Jakarta: Rieneka Cipta.

Echols, J. M dkk. 1990. Kamus Inggris - Indonesia. Jakarta: PT. Gramedia.

Furqon dan Emi Emilia. 2010. Penelitian Kuantitatif Dan Kualitatif. Bandung:

Sekolah Pasca Sarjana Universitas Pendidikan Indonesia.

Hakim, T. (2000). Belajar secara Efektif. Jakarta: Persada Swara

Hudoyo, H. (1985). Teori Belajar dalam PBM Matematika. Jakarta: Depdikbud.

Kelly, C. A. (2006). Using Manipulatives in Mathematical Problem Solving: A Performance-Based Analysis.TMME, vol3, no.2, p.184-193 2006 (CThe Montana Council of Teachers of Mathematics.

M. Chabib Thoha. 2003. Teknik Evaluasi Pendidikan. Jakarta: PT. Raja Grafindo Persada.

MS, Sukardi. 2008. Evaluasi Pendidikan Prinsip \& Operasionalnya. Jakarta : PT Bumi Aksara.

Purwanto, M. N. 2009. Prinsip-Prinsip Dan Teknik Evaluasi Pengajaran. Bandung: Remaja Rosdakarya. . 2010. Psikologi Pendidikan. Bandung: Remaja Rosdakarya.

Ruseffendi, ET. (2006). Pengantar kepada Membantu Guru Mengembangkan Kompetensinya dalam Pengajaran Matematika untuk Meningkatkan CBSA. Edisi Revisi. Bandung: Tarsito.

Santyasa, I. W. (2009). Metode Penelitian Pengembangan dan Teori Pengembangan Modul. Makalah Disajikan dalam Pelatihan Bagi Para Guru TK, SD, SMP, SMA, dan SMK Tanggal 12-14 Januari 2009, di Kecamatan Nusa Penida Kabupaten Klungkung

Suherman, E. (2004). Model-Model Pembelajaran Matematika Berorientasi Kompetensi Siswa. Makalah disajikan dalam acara Diklat Pembelajaran bagi Guru-guru Pengurus MGMP Matematika di LPMP Jawa Barat tanggal 10 Desember 2004: Tidak Diterbitkan.

Suherman, E. dkk. (2003). Strategi Pembelajaran Matematika Kontemporer. Bandung: Depdiknas-JICA-UPI. 
Sudijono, Anas. 2003. Pengantar Evaluasi Pendidikan. Jakarta: PT Raja Grafindo Persada.

Turmudi. (2008). Landasan Filsafat dan Teori Pembelajaran Matematika (berparadigma Eksploratif dan Investigasi). Jakarta: Leuser Cita Pustaka.

William, Mahrens. 1956. Measurement and Evaluation. USA: Holt, Reinhart and Winston, Inc.

Wrightstone. 1965. Evaluation in Modern Evaluation. Newyork: American Book Company.

Zainal, Arifin. 1988. Evaluasi Instruksional. Bandung: CV Remadja Karya. 